\title{
Communication
}

[Comunicação]

\section{Ovarian cholesteatoma in a bitch}

[Colesteatoma ovariano em uma cadela]

\author{
R.G. Oliveira, F.B. Fukushima, E.F. Nascimento, R.L. Santos* \\ Escola de Veterinária - UFMG \\ Caixa Postal 567 \\ 31270-901 - Belo Horizonte, MG
}

\begin{abstract}
Cholesteatoma (also known as cholesterol granuloma) is a benign non neoplastic tumor-like lesion. It is well circumscribed and typically asymptomatic, often described as an incidental finding at necropsy. Usually, the cholesteatoma is a slow growing mass with relatively little destruction of surrounding tissues (Jackson et al., 1994). However, compression of adjacent tissues may result in significant clinical signs.
\end{abstract}

Cholesteatomas are rarely reported in animals, except in horses, which are more commonly affected. It occurs more often in the choroid plexus of horses, with approximately 15 to $20 \%$ of old horses having this lesion (Maxie and Youssef, 2007). In the dog, cholesteatoma has been reported mostly in the middle ear associated with chronic otitis media (Little et al., 1991). There are three recently reported cases of intraocular cholesteatomas in Miniature Schnauzer dogs with diabetes mellitus (Zarfoss and Dubielzig, 2007). Genital cholesteatomas are extremely rare lesions, with only one report in domestic animals, affecting the uterus of a 12 year-old cat (Zanghi et al., 1999). In humans, cholesteatomas are uncommon, with a few reports of this lesion affecting the genital system, including two cases of cholesteatoma in the ovary (Bekker, 1959, Minkowitz et al., 1965), and a few other reports of cholesteatoma in the male genital system, affecting the epididymis (Spajic et al., 2006) and the spermatic cord (Pak et al., 1988). To the best of our knowledge this is the first documented case of ovarian cholesteatoma in a domestic animal.

A 15-year-old Yorkshire bitch, which has never been pregnant, was admitted to the Veterinary Hospital with a history of vaginal bleeding for the past ten days. Clinically, the abdomen was distended, there was a palpable intra-abdominal nodule in the right latero-dorsal abdomen, and the animal exhibited abdominal pain at examination. After a presumptive diagnosis of pyometra, the animal underwent ovariohysterectomy.

The right ovary was grossly enlarged (4 x 3 x $2 \mathrm{~cm}$ ), firm, with an irregular whitish surface (Fig. 1). Histologically, it had extensive areas with cholesterol clefts and accumulation of a high number of macrophages with a vacuolated cytoplasm, and some multinucleated giant cells (Fig. 1). There was fibrosis in the adjacent ovarian cortex, with abundant coarse collagen fibres as demonstrated by Masson's trichrome staining, with a mild multifocal perivascular lymphocytic infiltrate and a small focal infiltration of neutrophils adjacent to germinal epithelium in the cortex. There was also multifocal accumulation of macrophages containing a yellow intra-cytoplasmic pigment interpreted as lipofuscin, and several macrophages containing intra-cytoplasmic brown pigment identified as hemossiderin by the Prussian blue staining. Sections stained with

Recebido em 20 de fevereiro de 2008

Aceito em 7 de outubro de 2008

*Autor para correspondência (corresponding author)

E-mail: rsantos@vet.ufmg.br 
picrossirius examined under polarized light demonstrated predominantly type I collagen in areas of fibrosis, whereas delicate fibres of type III collagen predominated among cholesterol clefts and macrophages. This lesion resulted in compression and hypotrophy of the ovarian cortex, which did not have any functional structures such as developing follicles or corpus luteum. In contrast, the left ovary had multiple corpus luteum and no histological changes, indicating that the animals were at diestrus, which is compatible with the clinical manifestation of pyometra. These findings suggest that ovarian cholesteatoma can impair ovarian function by compressing the cortex causing hypotrophy, but there is no hormonal imbalance since the contralateral ovary was fully functional. Cicchini et al. (2002) considered ovarian cholesteatoma as a manifestation of teratoma, but they do not provide any data supporting this hypothesis. Moreover, in the present case no foreign tissue components were present in the affected ovary, which is the hallmark of ovarian teratomas.

Although the pathogenesis of cholesteatoma is not completely clear, the most accepted hypothesis, at least for cholesteatomas in the choroid plexus of horses, is that the lesion is secondary to congestion and haemorrhage (Maxie and Youssef, 2007). This mechanism might have played a role in the present case, since a high number of macrophages containing hemossiderin were observed, indicating previous haemorrhage. In addition, high levels of cholesterol may be a predisposing factor. An experimental lipid-rich diet increases the risk of occurrence of cholesteatomas in the choroid plexus of rabbits, but this correlation has not been described in humans (Muenchau and Laas, 1997). Furthermore, diabetes mellitus-induced hyperlipidemia appears to be a predisposing factor for intra-ocular cholesteatomas in dogs (Zarfoss and Dubielzig, 2007). In the present case, no laboratory data about the levels of cholesterol were available.

The absence of previous reports on canine ovarian cholesteatoma indicates that it is an extremely rare condition, with an obscure pathogenesis, and it can impair the function of the affected ovary.

Keywords: bitch, cholesteatoma, cholesterol granuloma, ovary

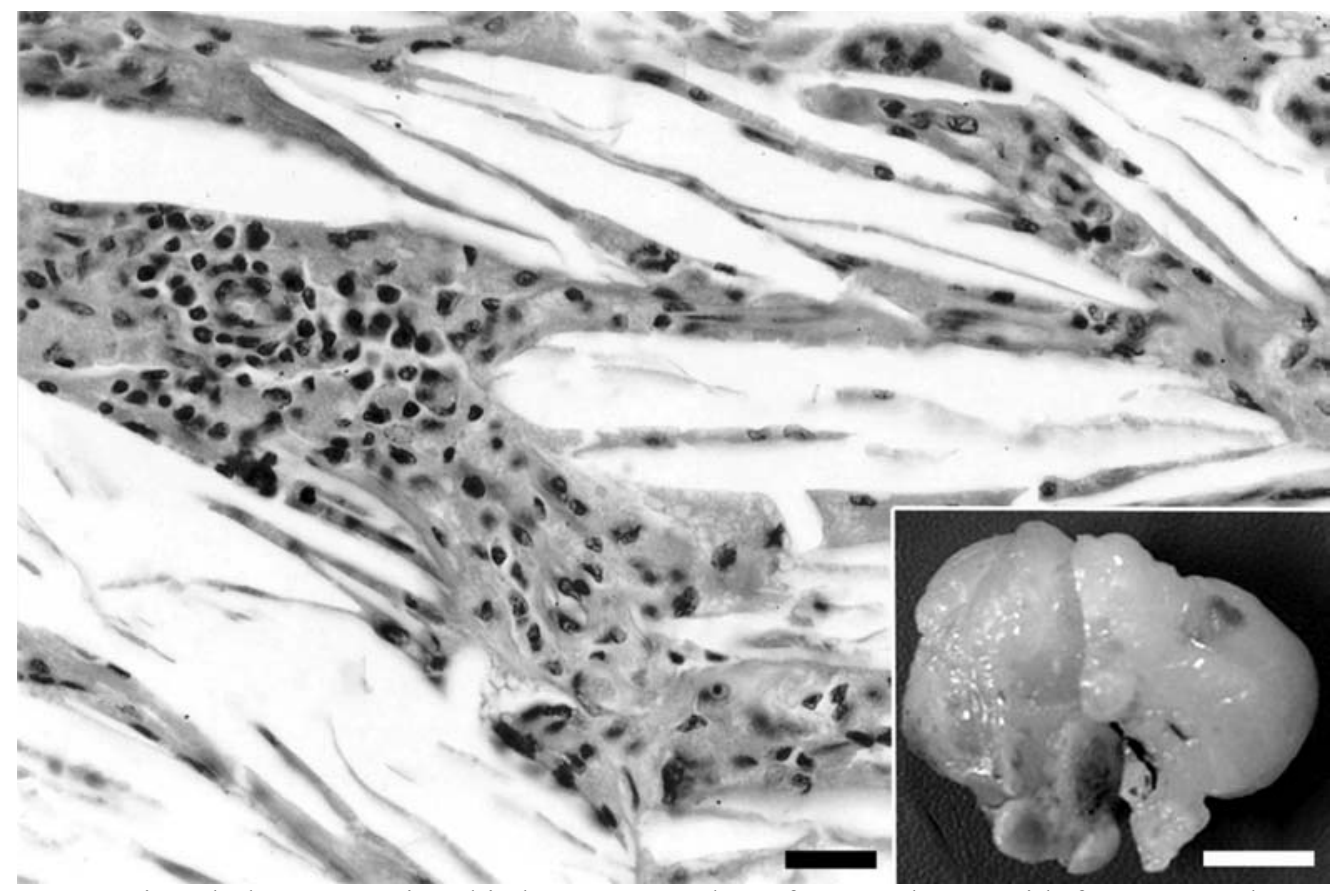

Figure 1. Ovarian cholesteatoma in a bitch. Large number of macrophages with foamy cytoplasm, a few multinucleated cells, and perivascular lympho-plasmacytic infiltrate, with several cholesterol clefts (bar: $25 \mu \mathrm{m})$; hematoxylin and eosin. Detail: Gross appearance of the affected ovary (bar: $1 \mathrm{~cm})$. 


\section{RESUMO}

O presente relato descreve um caso de colesteatoma ovariano em uma cadela Yorkshire de 15 anos de idade. $O$ diagnóstico clínico foi de piometra e o animal foi submetido a ovariosalpingohisterectomia. $O$ ovário esquerdo apresentava-se aumentado de volume $\left(\begin{array}{lllll}4 & x & 3 & 2 \mathrm{~cm}\end{array}\right)$, firme e esbranquiçado. Histologicamente havia grande número de cristais de colesterol, com acúmulo de macrófagos e algumas células gigantes multinucleadas. A lesão resultou em compressão do córtex ovariano adjacente que não continha nenhuma estrutura funcional, como folículos e corpo lúteo. O ovário contralateral não apresentava nenhuma alteração e continha múltiplos corpos lúteos.

Palavras-chave: cadela, colesteatoma, granuloma de colesterol, ovário

\section{REFERENCES}

BEKKER, G.M. Cholesteatoma of the ovary. Akush. Ginekol., v.35, p.97-99, 1959.

CICCHINI, C.; LARCINESE, A.; RICCI, F. et al. Monodermal highly specialized teratoma of the ovary: a sebaceous gland tumor. Eur. J. Gynaecol. Oncol., v.23, p.442-444, 2002.

JACKSON, C.A.; DELAHUNTA, A.; DYKES, N.L. et al. Neurological manifestation of cholesterinic granulomas in three horses. Vet. Rec., v.135, p.228-230, 1994.

LITTLE, C.J.; LANE, J.G.; GIBBS, C. et al. Inflammatory middle ear disease of the dog: the clinical and pathological features of cholesteatoma, a complication of otitis media. Vet. Rec., v.128, p.319-322, 1991.

MAXIE, M.G.; YOUSSEF S. Nervous system. In: JUBB, K.V.F.; KENNEDY, P.C.; PALMER, N. Pathology of domestic animals. 5.ed. San Diego: Academic, 2007. p.281-457.
MINKOWITZ, S.; FRIEDMAN, F.; HENNIGER, G. Xanthogranuloma of the ovary. Arch. Pathol., v.80, p.209-212, 1965.

MUENCHAU, A.; LAAS, R. Xanthogranuloma and xanthoma of the choroid plexus: evidence for different etiology and pathogenesis. Clin. Neuropathol., v.16, p.72-76, 1997.

PAK, K.; TOMOYOSHI, T.; OKABE, H. Xanthogranuloma of the spermatic cord. Eur. Urol., v.15, p.277-280, 1988.

SPAJIC, B.; CUPIC, H.; STIMAC, G. et al. Cholesterol granuloma of the right epididymis mimicking an acute scrotum. Asian J. Androl., v.8, p.749-750, 2006.

ZANGHI, A.; NICOTINA, P.A.; CATONE, G. et al. Cholesterol granuloma (Xanthomatous metritis) in the uterus of a cat. J. Comp. Pathol., v.121, p.307-310, 1999.

ZARFOSS, M.K.; DUBIELZIG, R.R. Solid intraocular xanthogranuloma in three Miniature Schnauzer dogs. Vet. Ophthalmol., v.10, p.304307, 2007. 